\title{
Description of Knowledge and Attitude of Prospective Hajj Pilgrims KBIH Mandiri 2019 in Malang City About Hypertension
}

\author{
Riskiyah $^{* 1}$, Hanun Shafira Qatrunnada ${ }^{1}$, Ektina Naura Barbara Ulfa ${ }^{1}$ \\ ${ }^{1}$ Department of Public Health Sciences, Faculty of Medical and Health Sciences, Universitas Islam Negeri Maulana Malik Ibrahim \\ Malang, Indonesia \\ *E-mail: riskiyahdr@gmail.com
}

\begin{abstract}
Hypertension is one of the diseases that can cause people's death and it usually does not give any symptoms. Hypertension often occurs to the pilgrims. Knowledge and proper attitudes about hypertension of prospective pilgrims from Indonesia, especially in Malang City (East Java), are expected to reduce morbidity and mortality rates because they can manage their illness, properly. The purpose of this study is to describe the level of hypertension-related knowledge and attitudes of prospective pilgrims from KBIH Mandiri 2019 in Muhajirin Mosque. The method used in this study is a descriptive cross-sectional study. 48 participants have participated in this study. They are the 2019 pilgrims from Indonesia. The results showed that 18 people (38\%) had good knowledge about hypertension, 17 people $(35 \%)$ are intermediately educated and 13 people (27\%) are lack of knowledge. Furthermore, this study has indicated that 25 people (52\%) have positive attitudes and 23 people ( $48 \%$ ) have negative attitudes about hypertension. This study concluded that in the majority, the 2019 prospective pilgrims from Malang have good knowledge and acceptable attitudes about hypertension.
\end{abstract}

Keywords: Hajj pilgrims, hypertension, knowledge, attitude

\section{Introduction}

Hypertension is a disease that often occurs throughout the world [1]. According to WHO data in 2013, it was showed there are around 982 million people or $26.4 \%$ of the earth's inhabitants who suffer from hypertension with a ratio of $26.1 \%$ women and $26.6 \%$ men [2]. In 2025 , the prevalence of hypertension is estimated to increase by $60 \%$, around 1.56 million people who suffer from this disease [3]. Hypertension is the third biggest risk factor that causes premature death related to heart and blood vessel disease as well as affects the quality of life [4].

Hypertension is a disease that can be deadly because it often occurs without giving any symptoms so it has long been considered as the silent killer [5,6]. Hypertension can increase a patient's risk of heart attack, heart failure, stroke, and even kidney failure. In the other hand, hypertension is not a disease that can directly kill the sufferer. However, when it occurs with combination of other related disease, it could be extremely dangerous [5]. In Indonesia, there are still many people who do not know that they suffer from hypertension, this shows that the level of public awareness of health is still low [5].

An important factor in controlling blood pressure is the knowledge and awareness of patients about hypertension because, with this knowledge, patients will often consult a doctor and take medication regularly. Also, good knowledge of hypertension can reduce the morbidity and mortality of individuals affected by hypertension [7].

A preliminary study was conducted through unstructured interviews with six prospective KBIH Mandiri pilgrims in 2019 at Muhajirin Mosque in Malang, which consisted of three women and three men, show that most of them did not realize that they had hypertension. Two informants said that he had been suffering from hypertension for a long time but did not routinely take medication to reduce or control his blood pressure. KBIH Mandiri is a pilgrimage guidance group formed by the Muhajirin Mosque foundation in order to prepare prospective pilgrims to be able to carry out the pilgrimage properly in accordance with the requirements of the implementation of the pilgrimage. 
Every year around 200 thousand people who perform the pilgrimage and about $30-45 \%$ of the pilgrims suffer from high-risk diseases because they are categorized as elder people. Mostly, it was high-risk diseases and about 25-37\% are hypertension and diabetes mellitus. Hajj is a worship that requires excellent physical condition because the pilgrims do heavy physical activities. Furthermore, the environment characteristic in Saudi Arabia is different from Indonesia. These environmental differences can also affect the health of pilgrims [8].

Patients who have good knowledge and attitude about the disease influence the management of the illness. Controlled blood pressure, morbidity and mortality rates of patients can be influenced by information obtained and attitudes of these patients [9]. Most rural communities have poor knowledge, poor attitudes and bad practices towards hypertension because of their illiteracy. They do not know the prevention or a good lifestyle [9]. An assessment of the knowledge, attitudes is an important element of hypertension control, but little information is available from developing countries where hypertension has recently been recognized as a major health problem [10]. From the above background, researchers are interested in conducting research on the knowledge and attitudes of prospective pilgrims from $\mathrm{KBIH}$ Mandiri 2019 in Malang related to this hypertension.

\section{Methods}

In this study, researchers used a descriptive study by the cross-sectional approach to determine the level of knowledge and attitudes of prospective hajj pilgrims KBIH Mandiri
2019 in Malang. The number of samples in this study was 48 respondents of prospective KBIH Mandiri Pilgrims in 2019. The instrument used in this study was a questionnaire sheet consisting of 10 questions about knowledge and 10 statements about the attitudes of prospective pilgrims from KBIH Mandiri in 2019 towards hypertension. Data were analyzed descriptively then presented in tabular and narrative form.

\section{Results}

\subsection{Respondent data based on gender}

Data distribution based on gender showed in table 1. From the table, it can be concluded that the majority of respondents who are prospective KBIH Hajj pilgrims 2019 in Malang were female totally 27 respondents $(56.25 \%)$ while the remaining $21(43.75 \%)$ respondents were male.

\subsection{Respondent data description by Age}

The age of respondents in this study was divided into 4 categories, namely: 1) 30-39 years; 2) 40-49 years; 3) 50-59 years; 4)> 60 years. Based on the research, the results shown in the table 2. the majority of respondents who are KBIH Mandiri pilgrims in 2019 in Malang are between 50-59 years old, namely $30 \quad(62.50 \%)$ respondents, $10 \quad(20.83 \%)$ respondents aged 40-49 years, $7(14.58 \%)$ of respondents aged $>60$ years and the remaining $1(2.09 \%)$ of respondents aged 30-39 years.

Table 1

Distribution Based on Gender of the 2019 KBIH Mandiri Hajj Pilgrims Respondents in Malang

\begin{tabular}{cccc}
\hline No & Gender & Frequency & Percentage $(\%)$ \\
\hline 1 & Woman & 27 & 56,25 \\
2 & Men & 21 & 43,75 \\
\hline Total & & 48 & 100
\end{tabular}

Table 2

Age distribution of KBIH Mandiri Pilgrims in Malang 2019

\begin{tabular}{cccc}
\hline No & Age & Frequency & Percentage $(\%)$ \\
\hline 1 & $30-39$ Years & 1 & 2,09 \\
2 & $40-49$ Years & 10 & 20,83 \\
3 & $50-59$ Years & 30 & 62,50 \\
4 & $>60$ Years & 7 & 14,58 \\
\hline Total & & 48 & 100 \\
\hline
\end{tabular}

Table 3

Distribution of latest education of KBIH Mandiri Hajj Pilgrims Respondent in Malang 2019

\begin{tabular}{cccc}
\hline No & Latest Education & Frequency & Percentage $(\%)$ \\
\hline 1 & High School & 11 & 22,92 \\
2 & Diploma & 6 & 12,50 \\
3 & Bachelor & 24 & 50 \\
4 & Masters & 7 & 14,58 \\
\hline Total & & 48 & 100 \\
\hline
\end{tabular}


Table 4

Distribution of KBIH Mandiri Hajj Pilgrim's occupations in Malang 2019

\begin{tabular}{cccc}
\hline No & Occupation & Frequency & Percentage $(\%)$ \\
\hline 1 & Civil Servants & 18 & 37,50 \\
2 & Private & 9 & 18,75 \\
3 & Does not work & 10 & 20,83 \\
4 & Others & 11 & 22,92 \\
\hline Total & & 48 & 100 \\
\hline
\end{tabular}

Table 5

Distribution of respondents by the origin of information obtained about hypertension

\begin{tabular}{cccc}
\hline No & Information & Frequency & Percentage $(\%)$ \\
\hline 1 & Health Workers & 30 & 54,55 \\
2 & Family/Neighbors & 6 & 10,91 \\
3 & Online Media & 5 & 9,09 \\
4 & Print Media & 4 & 7,27 \\
5 & Scientific Articles & 3 & 5,46 \\
6 & Television & 7 & 12,72 \\
\hline Total & & 55 & 100
\end{tabular}

\subsection{Latest education data of respondents}

The last education of respondents in this study was divided into several categories, namely SMA, Diploma, Bachelor and Masters. Table 3 shows that the majority of respondents who were $2019 \mathrm{KBIH}$ Mandiri Hajj Pilgrims in Malang were educated last year with as many as $24(50 \%)$ respondents, $11(22.92 \%)$ respondents with the last high school education, $7(14.58 \%)$ respondents last educated Masters, $6(12.50 \%)$ respondents were last educated Diploma.

\subsection{Respondent data based on occupation}

The occupation of respondents for this study was divided into four categories including 1) Civil Servants; 2) Private; 3) Doesn't Work; and 4) Others. The frequency distribution is presented to describe the majority of respondent's occupations and shows the number and percentage of each job category. Table 4 shows that the majority of respondents (18 respondents) who were KBIH Mandiri 2019 Hajj Pilgrims in Malang worked as civil servants (37.50\%), 11 $(22.92 \%)$ respondents worked others, 10 (20.83) \%) respondents did not work, and $9(18.75 \%)$ respondents worked privately.

\subsection{Respondent data based on the origin of information obtained about hypertension}

The origin of information obtained by respondents about hypertension in this study is divided into six categories, namely: 1) Health workers; 2) Family / Neighbors; 3) Online Media; 4) Print Media; 5) Scientific Articles; 6) Television. Table 5 shows that the majority of respondents who were 2019 KBIH Hajj Pilgrims in Malang received information about hypertension from health workers in 30 (54.55\%) respondents, $7(12.72 \%)$ respondents received information from television, $6(10.91 \%)$ respondents get information from neighbors or family, $5(9.09 \%)$ respondents get information from online media, $4(7.27 \%)$ respondents get information from print media and the remaining 3 (5.46) respondents get information from scientific articles. The number of respondents who received information about hypertension did not reflect the actual number because several respondents chose more than one answer about where they got information about hypertension.

\subsection{Hypertension history of respondents}

Respondents who get suffering hypertension were divided into two categories: 1) Yes; and 2) No. The frequency distribution is presented to illustrate how many respondents suffering hypertension or not. Table 6 shows that the majority of respondents who were KBIH Mandiri Pilgrims in 2019 in Malang City did not suffer from hypertension as many as $39(81.25 \%)$ respondents, while the remaining $9(18.75 \%)$ respondents suffered from hypertension. 
Table 6

Distribution of respondents based on their hypertension history

\begin{tabular}{cccc}
\hline No & Suffers from hypertension & Frequency & Percentage $(\%)$ \\
\hline 1 & Yes & 9 & 18,75 \\
2 & No & 39 & 81,25 \\
\hline Total & & 48 & 100 \\
\hline
\end{tabular}

Table 7

Knowledge level of KBIH Mandiri hajj pilgrims in Malang 2019 about hypertension

\begin{tabular}{cccc}
\hline No & Knowledge & Frequency & Percentage $(\%)$ \\
\hline 1 & Well & 18 & 38 \\
2 & Enough & 17 & 35 \\
\\
Total & Minus & 13 & 27 \\
\hline
\end{tabular}

Table 8

Knowledge level of respondents based on socio-demography aspects

\begin{tabular}{|c|c|c|c|c|}
\hline \multirow{2}{*}{\multicolumn{2}{|c|}{ Socio-demography }} & \multicolumn{3}{|c|}{ Knowledge Levels } \\
\hline & & \multirow{2}{*}{$\begin{array}{c}\text { Good } \\
11\end{array}$} & \multirow{2}{*}{$\begin{array}{c}\text { Enough } \\
8\end{array}$} & \multirow{2}{*}{$\begin{array}{c}\text { Less } \\
8\end{array}$} \\
\hline Gender & Woman & & & \\
\hline & Men & 7 & 9 & 5 \\
\hline \multirow[t]{4}{*}{ Age } & 30-39 Years & 0 & 0 & 1 \\
\hline & 40-49 Years & 5 & 2 & 3 \\
\hline & 50-59 Years & 12 & 9 & 9 \\
\hline & $>60$ Years & 1 & 6 & 0 \\
\hline \multirow[t]{4}{*}{ Education } & High School & 4 & 4 & 3 \\
\hline & Diploma & 4 & 2 & 0 \\
\hline & Bachelor & 7 & 9 & 8 \\
\hline & Masters & 3 & 2 & 2 \\
\hline \multirow[t]{4}{*}{ Work } & Civil Servants & 7 & 7 & 4 \\
\hline & Private & 4 & 2 & 3 \\
\hline & Not Working & 5 & 3 & 2 \\
\hline & Others & 2 & 5 & 4 \\
\hline
\end{tabular}

Table 9

Attitude to hypertension of respondents

\begin{tabular}{ccc}
\hline Attitude & Frequency & Percentage $(\%)$ \\
\hline Accepting & 25 & 52 \\
Rejecting & 23 & 48 \\
\hline A total of & 48 & 100 \\
\hline
\end{tabular}

\subsection{Knowledge level of respondents about hypertension}

The level of knowledge of respondents in this study was divided into three categories, namely: 1) Good; 2) Enough; 3) Less. Good categorization if the answer is correct $\geq 75 \%$, enough if the answer is correct $<75 \%$, if the answer is correct $<50 \%$. For knowledge about hypertension, there are ten questions consisting of four questions about the definition of hypertension, one question about hypertension symptoms, one question about hypertension complications, one question about hypertension risk factors, two questions about hypertension prevention, and one question about hypertension therapy. Table 7 shows that the majority of respondents' knowledge levels which were $2019 \mathrm{KBIH}$ Mandiri Hajj Pilgrims in Malang were good, namely 18 $(38 \%)$ respondents, $17(35 \%)$ respondents had sufficient knowledge and the remaining $13(27 \%)$ respondents were respondents who have a lack of knowledge. Table 8 shows knowledge level of respondent classified by their sociodemography data.

\subsection{Attitudes of prospective KBIH Mandiri hajj pilgrims in Malang 2019 about hypertension}

The level of attitude of respondents in this study was divided into two categories, namely: 1) accepting and 2) rejecting. There are ten questions about this attitude in which 
the respondent must choose one of the answers among the very to agree, agree, doubt, disagree, strongly disagree. There are six attitude questions about the lifestyle of hypertensive patients, three questions about the attitude of hypertensive patients when to go to the doctor, 1 question about the attitude to take hypertension medication regularly. Table 9 shows that the majority of respondents who were prospective KBIH Mandiri pilgrims in 2019 Malang were accepting as many as $25(52 \%)$ respondents and $23(48 \%)$ respondents were respondents who had an attitude of refusing.

\section{Discussion}

The results showed that the number of prospective $\mathrm{KBIH}$ Mandiri pilgrims in 2019 with a good knowledge category of 18 people (38\%), which can be seen in table 7. This is influenced by the fact that most of the respondents have a college education of $24(50 \%)$ respondents, which can be seen in table 3 . This is consistent with the research conducted by Sadeq and Lafta (2017) found that there is a direct relationship between knowledge and education level. We hope that higher education can increase public awareness about health problems, especially those related to chronic diseases that they have [1]. Someone who has a low level of education in the development of his attitude in getting new information will be slow [11].

Education is a learning process in improving abilities so that later educational goals can be independent. The level of education also determines whether or not someone is easy to absorb and understand the knowledge they have acquired. The higher a person's education, the better his knowledge [12]. According to a journal written by Othman et al. (2011) that the level of education can affect individual perceptions and processing information related to health information received [13]. Another study conducted by Widayati et al. in 2012 also said that education is very influential in knowledge. The higher the level of one's education, the easier it is for people to receive information. The more information received, the easier and faster for a person to update his knowledge and form a complete cognitive foundation on a matter [14].

Apart from educational factors, the level of knowledge can also be influenced by age. According to Notoatmodjo (2005) that a person's comprehension and mindset can be influenced by age whereas he gets older the more his comprehension and thought patterns develop so that the knowledge he gets is getting better. Critical thinking skills also increase regularly during adulthood [15]. In this study the majority of the age of prospective pilgrims aged between $50-59$ years by $30(62.50 \%)$ respondents, which can be seen in table 2. At this age, respondents were able to understand well about hypertension because they had received information from various sources and personal experience.

The majority of respondents in this study were 27 women $(56.25 \%$ ) (table 1). Women and men have different responses about dealing with health problems where men tend not to care and not pay attention to their health but women care more about their health and prefer to do health checks [16]. Green revealed that attitude is one of the factors that can influence health behavior. Someone who has a good attitude and has personal experience will influence and impact on his health [17]. Based on the results of the study showed that the number of KBIH Mandiri pilgrims in 2019 with an accepting attitude category of $25(52 \%)$ respondents. This study is aligned with the research of Heriyadi et al., (2017) found that respondents who have a good attitude then the effort to control hypertension is also done well. Attitude will affect one's behavior [17]. A good attitude is expected to lead to good behavior although not always [18]. Attitude is one of the factors that can affect a person's health value and can determine the right way of controlling people with hypertension [17]. The better a person's attitude towards health, the health level of a person will also be better [19]. This can be seen from the results of the study that most respondents did not have hypertension because of their positive attitude about hypertension.

In this study the most respondents received information about hypertension was obtained from health workers. This is the following research conducted by Shadeq and Lafta (2017) that the source of information in their respondents was also obtained from health workers [1]. The provision of health information is expected to prevent and reduce the incidence of disease and as a means of health promotion [20]. Health education is an effort or activity to help individuals, groups, or communities in improving the ability (behavior) to achieve optimal health [21].

\section{Conclusion}

Most of the prospective pilgrims from KBIH Mandiri 2019 in Malang who came at the same time with data collection had good knowledge and an accepting attitude about hypertension. It is hoped that with good knowledge and attitude about hypertension, it can reduces mortality and more severe illnesses so that they can make the pilgrimage to its full potential.

\section{References}

[1] Sadeq R, Lafta RK. 2017. Knowledge, attitude and practice about Hypertension in Hypertensive Patients Attending Hospitals in Baghdad, Iraq. South East Journal of Public Health. 7(1): 29-34. 
[2] Susanto Y, Alfian R. 2015. Perbaikan Perilaku dan Tekanan Darah Pasien Hipertensi di RSUD DR. H. Moch. Ansari Saleh Banjarmasin setelah Pemberian Leaflet Edukasi Hipertensi dan Terapinya. Jurnal Ilmiah Manuntung. 1(2):140-144.

[3] Widyasari DF, Candrasari A.2010. Peningkatan Pengetahuan tentang Hipertensi Pada Lansia di Posyandu Lansia Dukuh Gantungan Desa Makamhaji Kartasura Sukoharjo. WARTA. 13(1): 28-36.

[4] Malonda NS, Dinarti LK, Pangastuti R. 2012. Pola Makan dan Konsumsi Alkohol sebagai Faktor Risiko Hipertensi Pada Lansia. Jurnal Gizi Klinik Indonesia, 8(4):202-212.

[5] Seke PA, Bidjuni HJ, Lolong J. 2016. Hubungan Kejadian Stres dengan Penyakit Hipertensi Pada Lansia di Balai Penyantunan Lanjut Usia Senjah Cerah Kecamatan Mapanget Kota Manado. E-journal Keperawatan (e-KP). 4(2):1-5.

[6] Kusumawaty J, Hidayat N, Ginanjar E. 2016. Hubungan Jenis kelamin dengan Intensitas Hipertensi pada Lansia di Wilayah Kerja Puskesmas Lakbok Kabupaten Ciamis. Mutiara Medika. 16(2):46-51.

[7] Wulansari J, Ichsan B, Usdiana D, 2013. Hubungan Pengetahuan tentang Hipertensi dengan Pengendalian Tekanan Darah Pada Pasien Hipertensi di Poliklinik Penyakit Dalam RSUD DR. Moewardi Surakarta. Biomedika. 5(1):1722.

[8] Wahjudi P, Putriana MF. 2014. Karakteristik dan Status Kesehatan Jamaah Haji Kabupaten Banyuwangi Tahun 2012. Jurnal IKESMA. 10(1):1-12.

[9] Naseem S, Sarwar MH, Afzal M, Gilani SA. 2018. Knowledge Attitude and Practice Toward Hypertension Among Adult Population in Rural Area of Lahore, Pakistan. International Journal of Scientific \& Engineering Research. 9(Issue 5):1674-1679.

[10] Patnaik L, Paul KK, Pattnaik S, Sahu T. 2017. Lifestyle Pattern and Hypertension Related Knowledge, Attitude and Practices among Diagnosed Patients of Hypertension Attending a Tertiary Care Hospital. J Cardiovasc Disease Research. 8(4):108-111.

[11] Susiati I, Hidayati T, Yuniarti FA. 2016. Gambaran Pengetahuan dan Sikap Klien tentang Cara Perawatan Hipertensi. Jurnal Care. 4(3):105-110.

[12] Ar-Rasily OK dan Dewi PK. 2016. Faktor-Faktor yang Mempengaruhi Tingkat Pengetahuan Orang Tua Mengenai Kelainan Genetik Penyebab Disabilitas Intelektual di Kota Semarang. Jurnal Kedokteran Diponegoro. 5(4):1422-1433.

[13] Othman, Nor, Sheau F. Y., Yu G. W. 2011. Examining The Relationship Between Gender, Age, Education Level, and Social Cognitive Factors in Health Setting. International Journal of Business and Management. 6(9):79-91.

[14] Ivoryanto E, Sidharta B, Illahi RK. 2017. Hubungan Tingkat Pendidikan Formal Masyarakat terhadap Pengetahuan dalam Penggunaan Antibiotika Oral di Apotek Kecamatan Klojen. Pharmaceutical Journal of Indonesia. 2(2):31-36.

[15] Potter dan Perry (2009). Buku Ajar Fundamental Keperawatan: Konsep, proses, dan praktik. Jakarta: EGC.

[16] Herlina L, Wiarsih W, Etty R. 2013. Hubungan Dukungan Keluarga dengan Perilaku Lansia Dalam Pengendalian Hipertensi. Jurnal Keperawatan Komunitas. 1(2):108-115.
[17] Heriyandi, Hasballah K, Tahlil T. 2017. Pengetahuan, Sikap dan Perilaku Diet Hipertensi Lansia di Aceh Selatan. Jurnal Ilmu Keperawatan. 6(1):57-69.

[18] Purwaningrum, SW, Rini, TS, Saurina, N. 2018. Hubungan Tingkat Pengetahuan, Sikap dengan Perilaku Warga dalam Pemenuhan Komponen Rumah Sehat. Jurnal Fakultas Kesehatan Masyarakat. 12(Issue 1):53-59.

[19] Dirhan. 2012. Hubungan Pengetahuan, Sikap dan Ketaatan Berobat dengan Derajat Sistole dan Diastole Pasien Hipertensi di Puskesmas Sukamerindu Kota Bengkulu. Jurnal Ilmiah Farmasi. 9(1).

[20] Sudarsono EK, Sasmita JF, Handyasto AB, Arissaputra SS, Kuswantiningsih N. 2017. Peningkatan Pengetahuan tentang Hipertensi Guna Perbaikan Tekanan Darah pada Anak Muda di Dusun Japanan, Margodado, Sayegan, Sleman, Yogyakarta. Jurnal Pengabdian Kepada Masyarakat. 3(1):26-38.

[21] Notoatmodjo S., 2007. Kesehatan Masyarakat Ilmu dan Seni. Jakarta: Rineka Cipta p143-6. 